içine dahil etmesinden kaynaklanmaktadır. Böylelikle aslında maddi kültür öğesi olan giyimin Osmanlı ile Avrupa arasındaki kültüre nasıl sirayet ettiği ve bir bakıma rekabet nitelikli ilişkilerin nasıl ekonomik ve politik kimliğe dönüştüğü mukayese edilebilmektedir. Bilhassa Osmanlı ve Avrupa'nın ortak tarihi söz konusu olduğunda bu türlü geniş erimli mukayeselerin önemi daha iyi anlaşılabilecektir. Jirousek'in giyim üzerinden yaptığı da aslında böylesi bir mukayese girişimidir.

Murat Çelik

Ankara Yıldırım Beyazıt Üniversitesi

Ekmeleddin İhsanoğlu,

\title{
Medreseler Neydi, Ne Değildi? Osmanlılarda Akli İlimlerin Ĕ̈itimi ve Modern Bilimin Girişi,
}

İstanbul: Kronik Kitap, 2019, 446 p., ISBN 978-6-057-63532-7.

Prof. Dr. Ekmeleddin İhsanoğlu's new book released in November 2019 and titled Medreseler Neydi, Ne Değildi? Osmanlılarda Akli İlimlerin Eğitimi ve Modern Bilimin Girişi [What were Madrasas, What were They not? Instruction of Rational Disciplines and Introduction of Modern Science to the Ottomans] is a collection of essays published in the last decades. In the book's prefice Prof. İhsanoğlu stresses the newly emerged research interest in the madrasa history and "the nostalgia for the madrasa education" due to idealogical reasons rather than objective necessity. The extended introduction to the book puts forward the issue of how the madrasa history should be approached. İhsanoğlu argues that these institutions had never firmly sticked to a strict curriculum (müfredat) approved by the state or another authority. The trust deeds confirm that the variety of taught disciplines depended mostly on the established traditions rather than on legislation. İhsanoğlu disagrees with the previous scholarship and argues that the so-called "The Sultan's Syllabus" dating from $973 / 1565$ is just a list of textbooks to be provided and sent on an imperial order to the instructors (müderris) in the "imperial madrasas" (medaris- $i$ hakaniye). İhsanoğlu argues that this list did not necessarily mean a "curriculum" fixed by the sultan himself (Suleyman the Magnificent); rather it was an effort on behalf of the central authority to overcome the negligence and decay of 
instruction of some disciplines in the madrasas and to recover and strengthen the traditional educational mode. However, what the Ottoman sultans introduced to the madrasa tradition was their hierarchy based on the instructors' daily salary and the disciplines and textbooks to be taught.

In ten essays, arranged in accordance with the chronology of the historical periods taken into consideration, Prof. İhsanoğlu discusses in detail the origin and development of the madrasa institution throughout Islamic history. He develops George Makdisi's claim that the madrasas emerged in the $10^{\text {th }}-11^{\text {th }}$ centuries when only the traditionalist Islamic scholars prevailed over the rationalist ones after a long-lasting debate between them. İhsanoğlu argues that the madrasa institution emerged in responce to the nessecity of spreading the influence of Sunni-Ash'ari theological school during the $10^{\text {th }}-11^{\text {th }}$ centuries against the influence of Mu'tazila, the rationalist school in Islam. This led to the exclusion of rational disciplines from the madrasa instruction. As a reflection of the ongoing opposition between the traditionalist and rationalist discourses of Islamic thought the founders of some early $15^{\text {th }}$-century Ottoman madrasas banned the instruction of "philosophical disciplines". According to İhsanoğlu it was the reign of Mehmed the Conqueror (1451-1481) when the rationalist discourse gained more consideration and during the reign of Suleyman the Magnificent (1520-1566) both religious (nakli) and rational (akli) disciplines were ultimately integrated to the madrasa instruction.

The other major issue that Prof. İhsanoğlu preoccupies himself with is the incorrect comparison of the madrasa institution to the western colleges and universities. He underlines both the similarities and the differences between them and points out that they differ in origin, financement, and organization and argues that neither madrasas were taken as a pattern (with few exceptions) for the establishment of western colleges and universities, nor the latter's influence was in force well until the late $19^{\text {th }}$ century. İhsanoğlu rightfully questions the well established view in the previous scholarship that the madrasa complex of Mehmed the Conqueror built in 1470 and known under the name Sabn-ı Seman was the forerunner of Istanbul University (Darül-fünun) established only in 1900. Mehmed the Conqueror's complex consisting of eight madrasas together with eight preparatory schools (tetimme) was organized according to the traditional madrasa system, while Istanbul University was established by following the western pattern of institutional higher education. The only connection between the traditional madrasa system and the newly founded Ottoman university was the fact that 
some madrasa instructors gave lectures also in the university, and some madrasa students attended these lectures.

And thirdly, Prof. İhsanoğlu reveals in detail the introduction of modern western knowledge in the fields of astronomy, chemistry and other sciences to the Ottomans from the $17^{\text {th }}$ through the early $20^{\text {th }}$ century.

The book provides also an extended bibliography as well as an index. It is a useful and insighting compilation of Ekmeleddin İhsanoğlu's contributive works in the field of Islamic and Ottoman science history. I recommend this volume as a valuable and unavoidable source for both scholars and students of Islamic and Ottoman learning tradition, theory and history.

Orlin Sabev (Orhan Salih) Institute of Balkan Studies at the Bulgarian Academy of Sciences

Jonathan Eagles,

Stephen the Great and Balkan Nationalism: Moldova and Eastern European History,

London and New York: I. B. Tauris, 2014, $\mathrm{x}+272$ pages, ISBN 978-1-780-76353-8.

Jonathan Eagles' book, which is adapted from a postgraduate research undertaken at the Institute of Archeology, University College London, is a study on the figure of Stephen the Great [in Romanian Ştefan cel Mare], one of the pivotal characters in the Romanian history. The term "Romanian history" needs to be clarified here. As discussed in Eagles' work, Stephen the Great and his legacy are claimed by two independent but culturally and historically bound countries, Romanian and Moldavia, and their political discourse and historiographies.

The book consists an introduction, three main sections, a chapter titled "Postscript: Stephen the Great in the Moldovan Election Crisis of 2009", and chronology of the reign of the ruler, from his accession to his death in 1457 and aftermath until 1538, when Petru Rareş, the Prince of Moldavia were defeated by the Ottomans. In the first section titled "History", chapters provide a historical 